\title{
The Use of Educational Software in Teaching Physics in the Moroccan Context
}

\author{
https://doi.org/10.3991/ijet.v15i18.15455 \\ Jalal Khouna ${ }^{(凶)}$, Lotfi Ajana ,Ahmed Rhazal, Abdelilah El Mokri \\ Sidi Mohammed Ben Abdellah University, Fez, Morocco \\ jalal.khouna@usmba.ac.ma
}

\begin{abstract}
In the educational field, many researchers have studied the role played by the educational software in teaching physics. This review study aims to analyze the use of educational software in the teaching of physics in Moroccan secondary schools between the years 2010 and 2019. The sources for the data collection process were obtained through searches on Google Scholar pages. The analysis of the results allowed us to identify the advantages and disadvantages related to the integration of educational software in teaching physics in the Moroccan context. In addition, the study contributes with a set of recommendations for future use of educational software.
\end{abstract}

Keywords-Integration of educational software, physics, secondary schools, teaching, review study.

\section{Introduction}

In recent years, the use of information and communication technologies in education (ICTE) in Morocco has increased significantly, particularly in the area of teaching and learning of science [1]. This development is partly due to the promising speeches of the IT specialists, government institutions, government agencies, government economists and educators [2]. In this sense, we have chosen to study the impact of the use of educational software in the teaching of physics in Moroccan secondary school.

Educational Software includes all types of software used for educational purposes, whether intelligent or not, interactive or not [3]. Indeed, we can find a wide range of educational software that can be classified according to different criteria such as: The subject to be taught, the grade level, the hardware or software technology used, the evolution of the technology, the type of model implemented in the software [4] and the accessibility of the software. In relation to the pedagogical field, De Vries proposes a taxonomy made up of eight types of educational software classified according to the pedagogical function played by the software. This classification includes : tutorials, exercisers, the smart tutors, educational games, hypermedia, the simulators, the micro-worlds and the collaborators [5].

In teaching physics, software is used mainly as a laboratory tool during Computer assisted experimentation (CAEx) [6], a teaching aid, a communication and infor- 
mation tool [7]; [8], a simulator that replaces or complements an experiment, and as a tool for modelling and scientific calculation [9].

Moreover, the experimentation of educational software in the classroom is an ultimate and decisive step in the judgement of the effectiveness of these tools [10]. In fact, relevant educational software should be able to provide a plus compared to other teaching tools and/or learning materials already available in the classroom [11].

\section{$2 \quad$ Method}

In review studies, researchers use a variety of methods to select papers. Examples include selecting a defined set of manuscripts from interesting journals within research field [12] ; [13], selecting all articles published within the leading journals of the field [14] ; [15], and using databases in which the studies are indexed such as Google scholar.

\subsection{Research model}

The research model used in this review is content analysis, which is amongst the most frequently used qualitative research methods. The purpose of using this method is to reveal the facts behind the historical and current situation of the field of interest and provide more clarity for the data collected through this bibliometric analysis.

\subsection{Data collection}

The data of the study were obtained by searching Google scholar database covering articles published from 2010 to 2019. The database was searched with the keywords "educational software", "secondary education", "physics" and "Morocco". However, given that Morocco is a francophone country the same terms in Frensch were used in order to create a more comprehensive review.

\subsection{Data analysis}

The selection of articles was done by seeing the content of paper through the abstract that is significantly related to our criteria. The criteria are:

- Papers are related to our subject of research

- Papers discuss, about using educational software in teaching and learning physics in Moroccan context.

- Papers published from 2010 to 2019

- Papers are not a literature review

- Publishing type: Journals and seminar papers

Following our application of the criteria, 34 articles were found to be relevant to the purpose of the study. 


\section{Results and Discussion}

\subsection{Number of publications per year}

Total number of articles identified in Google scholar database after applying criteria are 34 papers published along a period of 10 years. The number of published papers per year is summarized in figure below:

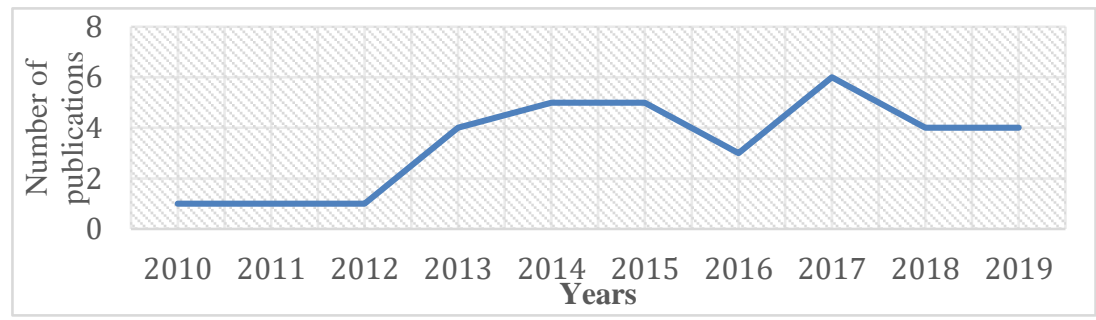

Fig. 1. Number of publications per year

It can be seen that the most work has been published between 2013 and 2019. The increment reflects the ongoing interest of Moroccan researchers regarding the use of educational software in teaching physics.

\subsection{The research methodology used in the selected articles}

In our research topic, we can find many methods of investigation; some studies are quantitative, qualitative or mixed in nature .Quantitative research method are low-cost and relatively simple to use by researchers, the majority of this type of research concerns teachers' views and learners' views about using educational software. In addition, research process is flexible and informal. Concerning qualitative studies, majority of them investigate the impact of using educational software on the learning process. Researchers who adopted mixed methods served the qualitative approach to strengthen the results from their quantitative procedure.

The data collection procedures for qualitative studies interested in using educational software included interviews and observations although quantitative studies used survey technique. Meanwhile, the use of educational software studies that used a mixed method approach have combined both methodologies by conducting surveys, interviews, and experiments.

The methodologies used in the selected articles were 19 (56\%) quantitative, 9 (26\%) qualitative, and 6 (18\%) mixed methods. (see fig. 2) 


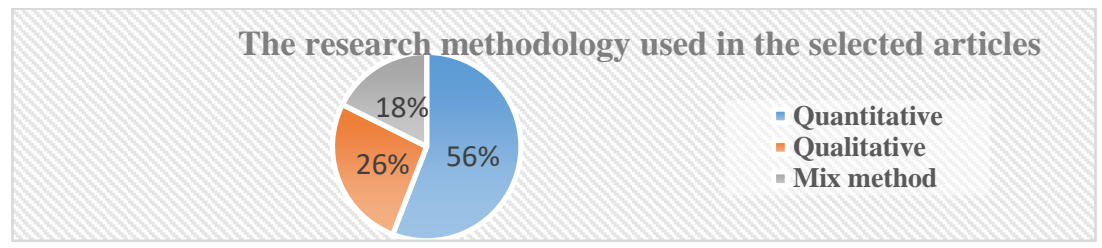

Fig. 2. The research methodology used in the selected articles

The data on methods of investigation indicate that most researcher tend to be far removed from what actually occurs in the learning processes. The majority of them studies the motivation and satisfaction of learners and teachers regarding the use of educational software.

\subsection{The contribution of using educational software}

Our review indicated that the use of educational software provide many advantages for the learners and the teacher in the teaching/learning process. Furthermore, the review considers multiple types of educational software without exception but over a third of articles found focus on the simulation software. (see fig. 3)

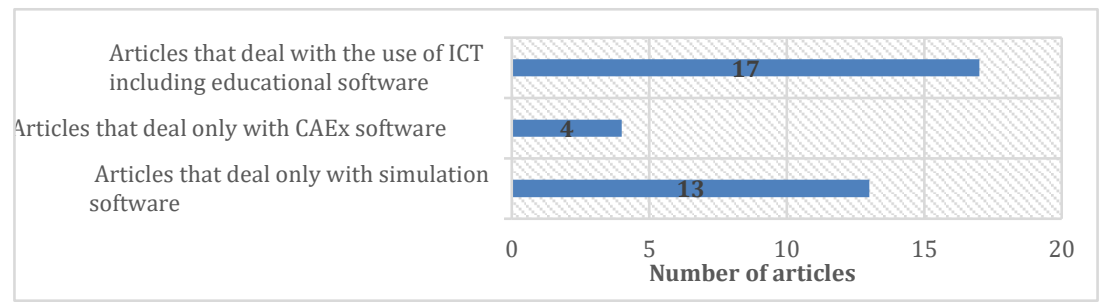

Fig. 3. Distribution of articles found according to the type of software.

Indeed, educational simulation software is the type most used by physics teachers in morocco [16];[17] .Many Moroccan researchers highlight the pedagogical value of simulation in science education [18]; [19]; [20] .

Droui and El Hajjami point out that these simulations are increasingly effective if they are integrated at the right time and for the right activity [18]. Other authors state that learners are aware of the complexity of learning concepts in physics and believe that the integration of simulation can help them to overcome certain obstacles in their learning processes and to assimilate physical concepts [21]; [22].

In fact, getting learners to work on educational software help them understand more the concepts they are taught in lectures [23], especially simulation was said to be useful for supporting learners, and for enabling their visualization of intangible physical concepts [24]; [25].

Utilizing educational software, learners can be more motivated and perform better [26]; [23]; [27]; [28]; [29] ; [30]; [20] , and enable a learner to perform experiments in the case of computer-assisted experimentation [30]; [31] . In fact, learner's motivation 
may have been due to the novelty of using educational software for some time, because, recently published results showed the opposite [23] ; [32].

Another study shows that there is a strong correlation between the use of simulation and achieving the learning goals [33]. Indeed, educational simulation software is a powerful and beneficial tool for learning, [25]; [34] and enables learners to become increasingly autonomous [33]. Furthermore, it is an alternative educational tool, which facilitates the cognitive task of learners [35].

The identified contribution was mainly related to the effects of educational software on the learners' performance. Researchers indicated that the learners who were involved in educational software activities improved their performance compared with the learners using traditional method, most of them justified by reasons of good understanding of physical concepts and simplifying a complex phenomenon. However, in the majority of this research, learning processes are not studied. Moreover, some researchers pointed out that there is no relationship between using educational software and learners' performance [36]; in fact, learner performances must involve other factors.

\subsection{The limits of using educational software}

There are many studies that indicate the lack of competence among physics teachers in using educational software due to a lack of training and skills, [37];[38];[39];[40];[41];[42];[43]; and the absence of a computer consultant at the high school to prepare and install educational software for teachers [44].

In fact, the average of competence of teachers in simulation software is less than $1 \%$ [40], although, the majority of teachers believe the importance of ICT integration in teaching [38]. Furthermore, in personal practices, teachers have a great mastery of the software [39]. Indeed, a survey showed that the majority of teachers expressed their desire to have special training in the use of educational software especially simulators [45].

On the pedagogical level, we found that some papers point out the lack of compatibility between the use of software and the pedagogical approach, also a lack of relevance of software to the curriculum [46]; [47]; [32]. In this sense, some researchers insist on the ability to find a good balance between the technical aspects of the software and the pedagogical relevance of each of its functionalities [11];[48].

According to the reviews of educational software articles, we found negative effects on the learning process, indeed, memorization is neglected because having access to an abundance and diversity of information, learners don't try to memorize certain rules or knowledge because they think that they will have access to this information [32]; [49] ; [50]. Moreover, the use of educational software can reduce learner' cognitive overload and language skills [49].

In fact, the excessive computer use could have a negative impact on academic performance if it influences the physical side of the learner [49]. In the same frame, the findings also indicated that the use of the educational software does not significantly influence success that means it is not obvious whether improved results are the result of a better understanding of the knowledge [36]. 
Following the same line, some researchers have found that the educational software is not a great motivational tool for Moroccan learners compared to other activity of learning [32]; [23], furthermore, the use of this software influences the learners' concentration [49] and engagement [32]. Therefore, learners do not acquire empowers autonomy and become dependent on this educational tool [30].

In summary, it will be seen that many of the areas report contradictory findings, and so it is difficult to be definitive for the impact of use of educational software in teaching physics .However, this tool can provide great educational benefits, as long as it does not negatively influence the learning process of learners.

\section{Conclusion}

The current study presented a snapshot of the research about the use of educational software in teaching physics in the Moroccan context, which is representative of a state of the art up to date. The systematic review, allowed us to identify not only the positive outcomes of the use of educational software but also the limits.

The findings from this study show that the use of educational software had educational value in teaching physics, such as; facilitating the understanding of physical phenomena, and improving the performance of learners in some cases. However, the use of these tools could have a negative impact on the learning process of learners. In addition, the use of software is beginning to lose its motivational value in the eyes of Moroccan learners.

Therefore, the following recommendations are proposed:

- It seems important to us to reflect on the most appropriate way to integrate educational software at the different steps of the learning process

- The use of educational software must be thought in terms of pedagogy

- Teachers must be trained to use educational software

- Introducing serious games in the teaching of physics in order to regain the learners' motivation

Future researchers may wish to analyze reviews, dissertations, and theses. It is possible that searching other databases will show other interesting results regarding the use of educational software in teaching physics.

\section{$5 \quad$ References}

[1] El Mhouti, A., Erradi, M., \& Nasseh, A. (2013). An Evaluation Model of Digital Educational Resources. International Journal Of Emerging Technologies In Learning (IJET), 8(2), pp. 29-35. https://doi.org/10.3991/ijet.v8i2.2501

[2] Carugati, F. \& Tomasetto, C. (2002). Le corps enseignant face aux technologies de l'information et de la communication : un défi incontournable. Revue des sciences de l'éducation, 28 (2), 305-324. https://doi.org/10.7202/007356ar 
[3] Macrelle-Rosselle Marilyne . Conception d'un atelier d'expérimentation de logiciels éducatifs.Application en géométrie. Education. Université Henri Poincaré - Nancy I, 2001. Français. (edutice-00000263)

[4] Dimitracopoulou A. et Komis V. (1999). Permettre aux élèves des activités multiples de modélisation et des approches interdisciplinaires à l'aide d'un nouveau environnement informatique, Actes des XXI journées internationales sur la communication, l'éducation et la culture scientifiques et techniques, Chamonix, p. 243-248

[5] De Vries Erica. Les logiciels d'apprentissage : panoplie ou éventail ?. In: Revue française depédagogie, volume 137, 2001. La pédagogie et les savoirs: éléments de débat. pp. 105116.DOI : https://doi.org/10.3406/rfp.2001.285

[6] Zakaria, N., Phang, F., \& Pusppanathan, J. (2019). Physics on the Go: A Mobile Computer-Based Physics Laboratory for Learning Forces and Motion. International Journal Of Emerging Technologies In Learning (IJET), 14(24), pp. 167-183. https://doi.org/10.3991/ ijet.v14i24.12063

[7] Beaufils, D., (2005). L'ordinateur outil de laboratoire en physique : quelles transpositions, Lyon : INRP.

[8] Alev, N. (2003). Integrating information and communications technology (ICT) into pre service science teacher education: The challenges of change in a Turkish faculty of education. PhD Thesis at the School of Education University of Leicester. https://lra.le.ac.uk/ bitstream/2381/4668/1/nedimalevtez.pdf

[9] Margaret Cox, «Informatique et apprentissage des sciences : tendances, dilemmes et conséquences pour l'avenir », RDST [Online], 6 | 2012, Online since 01 March 2015, connection on 13 September 2019. URL : https://journals.openedition.org/rdst/84; https://doi.org/ $10.4000 /$ rdst.84

[10] Ahaji, K., El Hajjami, A., Ajana, L., El Mokri, A, Chikhaoui, A. (2006). Études de quelques conceptions d'élèves de baccalauréat en optiques géométriques.

[11] Sjödén, B. (2015). What makes good educational software? Lund University Cognitive Studies, 164. https://lup.lub.lu.se/search/publication/7991505

[12] Hwang, G. J., \& Tsai, C. C. (2011). Research trends in mobile and ubiquitous learning: review of publications in selected journals from 2001 to 2010. British Journal o Educational Technology, 42(4), E65-E70.

[13] Nolen, A. L. (2009). The content of educational psychology: An analysis of top ranked journals from 2003 through 2007. Educational Psychology Review, 21(3), 279-289

[14] Karatas, S. (2008). Interaction in the Internet-Based Distance Learning Researches: Results of a Trend Analysis. The Turkish Online Journal of Educational Technology, 7(2), 1-9.

[15] Shih, M., Feng, J., \& Tsai, C.-C. (2008). Research and trends in the field of e-learning from

2001 to 2005: A content analysis of cognitive studies in selected journals. Computers \& Education, 51(2), 955-967.

[16] Mastafi, Mohammed. (2014). Intégration des TIC et typologie des usages dans le système éducatif marocain : Cas de l'académie régionale de l'éducation et de la formation Doukkala-Abda.

[17] Mohamed, Taoufik \& Abderrahim, Abouzaid \& Ahmed, Moufti. (2016). Les Activités Expérimentales Dans L'enseignement Des Sciences Physiques: Cas Des Collèges Marocains. https://doi.org/10.19044/esj.2016.v12n22p190

[18] Droui, M. et El Hajjami, A. (2014). Simulations informatiques en enseignement des sciences : apports et limites. EpiNet : revue électronique de l'EPI , 164. Récupéré du site de l'EPI : http://www.epi.asso.fr/revue/articles/a1404e.htm

[19] Daaif, Jabran \& Zerraf, Soufiane \& Tridane, Malika \& Benmokhtar, Said \& Belaaouad, S. (2019). Technological Innovation in Teaching and Research in Chemical Science: Development of a Computer Application for the Simulation of the Practical Works of Crystallography. 8. 2399-2405. 10.35940/ijrte.C4665.098319. 
[20] Salmi, K., Magrez, H., \& Ziyyat, A. (2014). Interactive simulation as a virtual tool in electromagnetics for online education. 2014 Third IEEE International Colloquium in Information Science and Technology (CIST). https://doi.org/10.1109/cist.2014.7016617

[21] Ahaji, K., Zahim, S., Droui, M. et Badda, B. (2013). Schéma d'évaluation pour le choix du multimédia pédagogique approprié. Consulté à l'adresse https://www.epi.asso.fr/revue/ articles/a1302e.htm

[22] Mohammed, Chekour \& Laafou, Mohamed \& Janati-Idrissi, Rachid. (2015). Distance Training for Physics Teachers in Pspice Simulator. Mediterranean Journal of Social Sciences. 6. https://doi.org/10.5901/mjss.2015.v6n3s1p232.

[23] Belkebir, N., \& Darhmaoui, H. (2018). Studio teaching model for an introductory engineering physics course on classical mechanics.

[24] Salmi, Khalid \& Magrez, Hamid \& Ziyyat, Abdelhak. (2019). Didactic Simulations for Electromagnetism Based on an Element Oriented Model. International Journal of Engineering Pedagogy (iJEP). https://doi.org/10.3991/ijep.v9i5.10696

[25] Karoum Limame and Salaheddine SAYOURI, "Pedagogical scenario and simulation of the Coriolis effect on a falling ball considered in a terrestrial referential," International Journal of Innovation and Applied Studies, vol. 13, no. 3, pp. 581-599, November 2015

[26] Boulmalf, Mohammed \& Semmar, Yassir \& Lakas, Abderrahmane \& Shuaib, K.. (2010). Teaching digital and analog modulation to undergradute Information Technology students using Matlab and Simulink. 685 - 691. https://doi.org/10.1109/educon.2010.5492513.

[27] Hassouny, El \& Kaddari, Fatiha \& Elachqar, Abdelrhani \& Alami, Anouar. (2014). Teaching/Learning Mechanics in High School with the Help of Dynamic Software. Procedia Social and Behavioral Sciences. 116. 4617-4621. https://doi.org/10.1016/j.sbspro.2014.01. $\underline{995}$.

[28] Droui, M., El Hajjami, A., Bouklah, M., \& Zouirech, S. (2013). Impact de l'apprentissage par problème sur la compréhension conceptuelle de la mécanique newtonienne. EpiNet: Revue électronique de l'EPI, 157.

[29] Ouardaoui, Abdelkrim \& Legrouri, Ahmed \& Darhmaoui, Hassane \& Loudiyi, Khalid. (2012). ICT Integration into Chemistry-Physics Classes In Middle Schools Through A Participatory Pilot Project Approach. Procedia - Social and Behavioral Sciences. 55. 232-238. https://doi.org/10.1016/j.sbspro.2012.09.499.

[30] Elkababi, Khadija \& Atibi, Azzeddine \& Radid, Mohamed \& Tridane, Malika \& Belaaouad, S.. (2017). Integration of the CAEx in the Education (Teaching) of the Physical Sciences in the Moroccan High School. New Trends and Issues Proceedings on Humanities and Social Sciences. 4. 2349-5219. https://doi.org/10.18844/gihss.v3i1.1754.

[31] Y. Khazri, A.AL Sabri, B. Sabir, H. Toumi, M. Moussetad, A. Fahli, "Remote Control Laboratory Experiments in Physics using LabVIEW", International Journal of Information Science \& Technology, Vol.1 No. 1, 2017

[32] Khouna, Jalal \& Ajana, Lotfi \& Rhazal, Ahmed \& Hajjami, Abdelkrim. (2017). Introducing Educational Games in the Teaching of Physics in Moroccan Secondary Schools. IOSR Journal of Research \& Method in Education (IOSRJRME). 07. 19-28. https://doi.org/10. 9790/7388-0704011928

[33] Chekour, M., Laafou, M. et Janati-Idrissi, R. (2015). Vers l'introduction du simulateur Pspice dans l'enseignement de l'électricité : Cas du Tronc commun Sciences au Maroc. EpiNet : revue électronique de l'EPI , 175. https://doi.org/10.5901/mjss.2015.v6n3s1p232

[34] Oussama Dardary, Zineb Azar, Malika Tridane, Said Belaaouad (2019) -Importance of using Simulation in Chemistry: the Case of Batteries, Accumulators and Electrolysis - International Journal of Recent Technology and Engineering (IJRTE) ISSN: 2277-3878, Volume-8 Issue-3, September 2019. https://doi.org/10.35940/ijrte.c5148.098319

[35] Chekour, M., Laafou, M., \& Janati-Idrissi, R. (2017). Impact de la simulation sur l'acquisition des concepts en électricité: cas des lycéens marocains. 
[36] Abderrahmane Ouazzani Touhami, Nadia Benjelloun, Mohammed Alami and Haddou Aouni, " Difficultés conceptuelles relatives à la construction d'une image virtuelle et impact d'un atelier java d'optique géométrique (AJOG) sur les productions des élèves », RDST, 14 | 2016, 187-210. https://doi.org/10.4000/rdst.1446

[37] Echchafi, I \& Hamid, Taouil \& Mohammed, Aboulouafa. (2017). The Integration of Computer Tools i To I.

[38] Eddif, Aâtika \& Larhzil, Hayat \& Touir, Rachid \& Majdoubi, H. \& Kenafi, Jamila \& Ouazzani, Hassan \& Boutsougame, Abdelaziz. (2016). Integration of Information and Communication Technologies in Education for Life, Earth Sciences, Physical and Chemical Sciences Teachers of the Secondary and College Level in Morocco: Reality and Aspirations. 7. 2222-2863.

[39] Lablidi, A., Nachit, B., Abourriche, A., Namir, A., \& Talbi, M. (2013). ICT Practice in Morocco's innovative teachers.

[40] Mahdi, Khalid \& Laafou, Mohamed. (2015). Qualifications of Physics Teachers in ICT to Integrate the Use of ICT in Moroccan Physics Schools: Obstacles and Solutions. Journal of Educational and Social Research. 5. 177-182. https://doi.org/10.5901/jesr.2015.v5n1p177.

[41] El Ouidadi, O., Essafi, K., Aboutajdyne, M., Sendide, K., \& Depiereux, E. (2011). Analyse des attitudes et des besoins des enseignants Marocains dans le domaine des TICE. Cas de l'académie (AREF) de FES-Boulemane, Maroc. Radisma, 7. https://doi.org/10.1787/88893 2994453

[42] Ouasri, A. \& Bouatlaoui, T.. (2019). Motivation et intérêt des élèves de collège marocain pour l'apprentissage des sciences physiques. 7. 10.5281/zenodo.3514627.

[43] Atibi, Azzeddine \& Elkababi, Khadija \& Radid, Mohamed \& Talbi, Mohammed. (2017). Difficulties encountered by Moroccan Student in Studying Oxydoreduction. 4. 2349-5219.

[44] Khalid Mahdi. L'impact des formations continues à distance aux enseignants des sciences physiques dans des logiciels de simulation informatique. Journal for Educators, Teachers and Trainers JETT Morocco Journal for Educators, Teachers and Trainers, 2018, 9. ffhal$01784065 \mathrm{ff}$.

[45] Mahdi, Khalid \& Mohammed, Chekour. (2014). The generalization of using the ICT in the work of the physics teachers in Moroccan schools: Obstacle of training courses and solutions. International Journal of Innovation and Applied Studies. 9. 829-834.

[46] Omar, A. \& Benjelloun, N. (2013). Intégration des TIC dans l'enseignement des sciences physiques au Maroc dans le cadre du programme GENIE : difficultés et obstacles. Revue internationale des technologies en pédagogie universitaire / International Journal of Technologies in Higher Education, 10 (2), 49-65.https://doi.org/10.7202/1035522ar

[47] Mamane, A.; Benjelloun, N. Study of the Dependence between the Teaching- Learning of Physics and the ICT Resources available to Pupils in Moroccan High Schools. IJEIS Int. J. Educ. Inf. Stud. 2018, 8, 1-15

[48] Andyani, H., Setyosari, P., Wiyono, B., \& Djatmika, E. (2020). Does Technological Pedagogical Content Knowledge Impact on the Use of ICT In Pedagogy?. International Journal Of Emerging Technologies In Learning (IJET), 15(03), pp. 126-139. https://doi.org/10. 3991/ijet.v15i03.11690

[49] Youssef, E. L., Jamil, A. M., \& KOUSKSOU, T.(2015) Utilisation pédagogique des systèmes d'information dans l'enseignement et l'apprentissage. proceeding -Workshop International sur les Approches Pédagogiques \& E-Learning

[50] Eloirdi, A., Mammad, K., Arfaoui, A., Chtibi, H., Diallo, M.C., Wallon, P. and Ahami, A. (2018) Study of Visual Perception and Working Memory in Moroccan Adolescents Attending School. Open Journal of Medical Psychology, 7, 82-90. 


\section{$6 \quad$ Authors}

Jalal khouna is a PhD student at the laboratory of Computer and Interdisciplinary Physics (LIPI)), ENS ( école normale supérieure), Sidi Mohammed Ben Abdellah University, Fez, Morocco.

Lotfi Ajana is professor at ENS (école normale supérieure), sidi Mohamed Ben Abdellah university, Fez Morrocco. Founding member and permanent member of laboratory of Computer and Interdisciplinary Physics (LIPI).

Ahmed Rhazal is a PhD student at the laboratory of Computer and Interdisciplinary Physics (LIPI)), ENS ( école normale supérieure), Sidi Mohammed Ben Abdellah University, Fez, Morocco.

Abdelilah El Mokri Is professor at ENS ( école normale supérieure) sidi Mohamed Ben Abdellah univesity,Fez Morrocco, member of laboratory of Computer and Interdisciplinary Physics (LIPI) .

Article submitted 2020-05-07. Resubmitted 2020-06-09. Final acceptance 2020-06-10. Final version published as submitted by the authors. 